\title{
TYPOLOGY AND TRENDOLOGY OF ORGANIZATIONAL CONSUMER MARKETS IN THE SLOVAK REPUBLIC
}

\author{
Katarína Lehutová, Štefan Cisko \\ University of Žilina, Žilina, Slovak Republic \\ E-mail: katarina.lehutova@fpedas.uniza.sk, stefan.cisko@fpedas.uniza.sk
}

\begin{abstract}
In general, every consumer tries to apply their rights, fight for them. The interest of traders is usually hidden somewhere in the background. The main aim of this paper is to summarize how important the organizations are, highlight the role they play in the society, their development in time, the authenticity, which distinguished it from the individual consumer and to describe their importance and impact on the social life and economics in the Slovak Republic. Research conducted in European countries showed that the recession had a significant impact on all types of consumers. The paper analyses the results of those researches and finally depicts if the situation is the same in the Slovak Republic using the statistic data analysis, description and comparison.
\end{abstract}

Key words: organizational consumers, consumer typology, consumer behavior, retailers.

\section{Introduction}

Consumers are considered to be the key factor of the consumer policy. Consumers are people who consume products and services gained on the market and they are the aim of all economic processes and relations which are realized in the society. The consumer is the bearer of the consumption and two main types can be defined: an individual consumer and secondly an organizational consumer. The Big Economic Encyclopedia defines the consumer as following: "it is a term used for identification of two different consumption units, the personal consumers and the organizational. The personal consumer is an individuality who purchases products and services for their own consumption, for the family member, family usage or as a present for another person. In all the mention cases, the product is bought for final consumption of individuals, so called final consumers. The second group of consumers is divided into some groups: private companies, state authorities (local, regional, national) and institution purchasing products, equipment and services to be able to provide their operation regardless of the fact if they are profitable or not. The activity which leads to consumer needs' satisfaction is called consumer interest." (Šíbl, 2002, p.15).

The objective of the paper is to describe the differences between the individual consumer and organizational one. The most important aim is to find whether the Slovak chain stores copy the European prediction "despite the fact that the rate of unemployment is really high and the purchase power decreases, the revenues of chain stores do not stagnate". The secondary research was done to prove or disprove the prediction. Research conducted in European countries showed that the recession had a significant impact on all types of consumers. The paper analyses the results of those researches and finally depicts if the situation is the same in the Slovak Republic using the statistic data analysis, description and comparison.

In this paper is realized first a literature review in order to identify consumers, their behavior, typology and trendology and to highlight the main features. Further, through a research from secondary sources, there were analyzed the main differences between individual 
PROBLEMS

OF MANAGEMENT

IN THE $21^{\text {st }}$ CENTURY

volume 3, 2012

54

and organizational consumer, the development of the European chain stores, changes in the consumers behavior and finally the situation in the Slovak Republic is portrayed.

\section{The Essence of Organizational Consumers}

First of all, it is important for traders to have appropriate information about consumers and different stimuli that influence them. The company that recognizes the changes in consumer's behavior considering the package of products, its price, advertisement, has a big competitive advantage over its competitors. That is the impulse for companies to search in details the connection between the marketing stimuli and the consumer's response.

The organizational markets are in some context similar to consumers markets, because in both there are people who are in the role of buyers and make decisions about purchase satisfying their needs. However, the organizational markets differ from the individual consumer markets. The structure of market and demand is divers as the number of organizational buyers is much smaller but their purchase is done in greater amounts, the demand is not placed in balanced conditions, but is concentrated geographically (the price depends on the travel costs). Secondly, the organizational demand copies the demand for consumers' products. It means that the producer has to follow and evaluate the information about the increase in the demand for consumer goods which are produced of particular material, row stocks etc. The demand elasticity of the organizational markets is in the short-term horizon lower than of the consumer goods markets. For instance, if the price of metal for automobile construction decreases, producers do not buy greater amounts of the metal and do not produce more automobiles these changes are to be carried out in the long-term horizon (Majtán, 2007, p. 102).

But not only the mentioned factors are to be considered as few more can be named. For instance, the professional approach of traders and consumers and the dominance of rational factors in the purchase decision making process. The rational factors may be divided into two main groups. One of them determines the demand for consumer goods and influences the value and the future consumption. In a comparison, the second group of factors affects the choice and selection of suppliers, e.g. price, travel costs and other sale conditions, the ability to maintain the standard quality, reputation of the supplier, availability and level of services, informational cooperation between the trader and the consumer (Hawkins et al., 1991).

It was defined that the organizational consumers are purchasing products and services in greater amounts. The basics of the organizational market success can be found in exact directness of its activities. The importance is given to the typology of consumers into 3 large parties, the type of industrial user who buys equipment, machinery, furniture and consecutively use them to equip the factories, laboratories and offices. The products they buy are not parts of their production. The type of producers who buy material, stocks and components which are processed and the type of traders, purchasing and selling the same product without any changes or modifications, form the basic organizational consumer trendology (Majtán, 2007).

The organizational markets could no longer simply produce, because the consumer needs and wants to be taken into account. They are noticeably influenced by various indicators which create their consumer behavior. Stašenková (2006, p.22) states that "consumer behavior is an important and constant decision-making process of searching, purchasing, using, evaluating and disposing of products and services". That is why it is necessary for the traders and manufacturers to be in the know with their typology and trendology. Some indicators of the consumer behavior can be recognized easily, for instance the economic one, the others are more difficult to identify; sociological and psychological (Dzurová, 2007). The interest of manufacturers and traders are usually suppressed but on the other hand they can be allowed to be used into such an extent "to which it may be helpful to the welfare and interest of the consumer" (Steffens, 2006, s. $65)$. 


\section{Problem of Research}

Since 2008, the slower global increase has contributed to the repression of commodity prices. Finally, it can partly cause the cost decrease. This type of price inflation may cause the improvement of profit margins and the slow increase of revenues (can be found at http:// ekonomika.sme.sk/c/6221801/maloobchodnici-maju-dovody-na-optimizmus-tvrdi-deloitte. html\#ixzz1kSw68Egx). In 2012 the global economic slowdown and the recession are expected. As a result, the decrease of retail consumption is noticeable and the rational and prospective consumer behavior is anticipated. On the other hand, despite the fact that the rate of unemployment is really high (it has its maximal value from 2004, more than $15 \%$ ) and the purchasing power decreases, the revenues of chain stores do not stagnate (Higham, 2010, p.17). This prediction was set for European market and the aim of this paper is to find if the development and trendology in the Slovak Republic in the time of recession really copies the given prerequisite. The research is based on the secondary researches done by different companies the research question is the same as the prediction given by the European Union.

\section{Research Focus}

The research carried out by company Deloitte in 2010 showed that the biggest retail trader of the world was an American company Wal-Mart Stores as they reached revenues of 418000 mil USD. Next rank belonged to a French store Carrefour with revenues of 119000 mil USD. Tesco store with revenues of 92000 mil USD achieved third rank and finally beat a German store Metro (Zamazalová, 2009). In the following pictures the evolution of the European stores, Carrefour, Tesco, Metro, are shown.

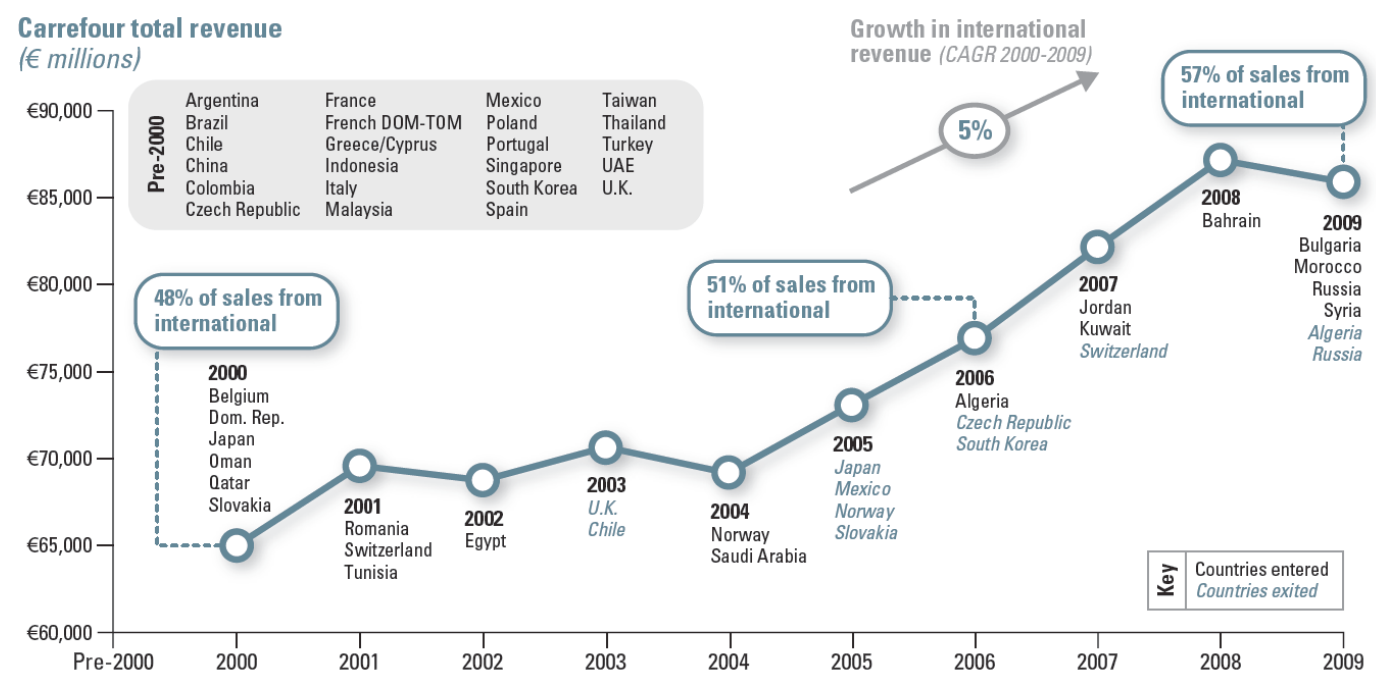

Source: http://www.atkearney.com/index.php/Publications/global-retail-development-index.html

Figure 1: Expand and revenues of Carrefour. 
PROBLEMS

OF MANAGEMENT

IN THE $21^{\text {st }}$ CENTURY

volume 3, 2012
Metro Group total revenue (€ millions)

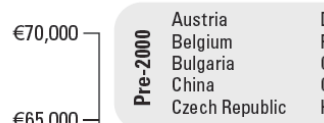

$€ 65,000$

$€ 60,000$

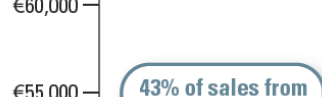

$€ 55,000-43 \%$ of sales from

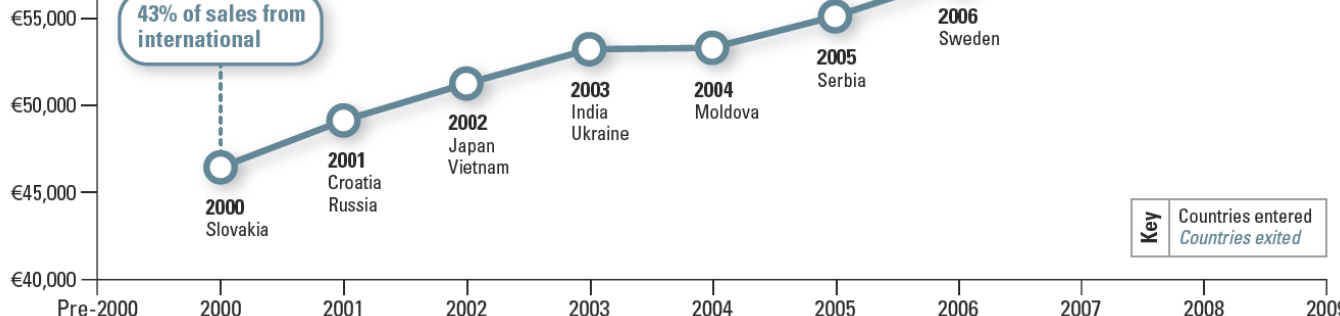

Source: http://www.atkearney.com/index.php/Publications/global-retail-development-index.html

Figure 2: Expand and revenues of Metro Group.

Tesco total revenue (£ millions)

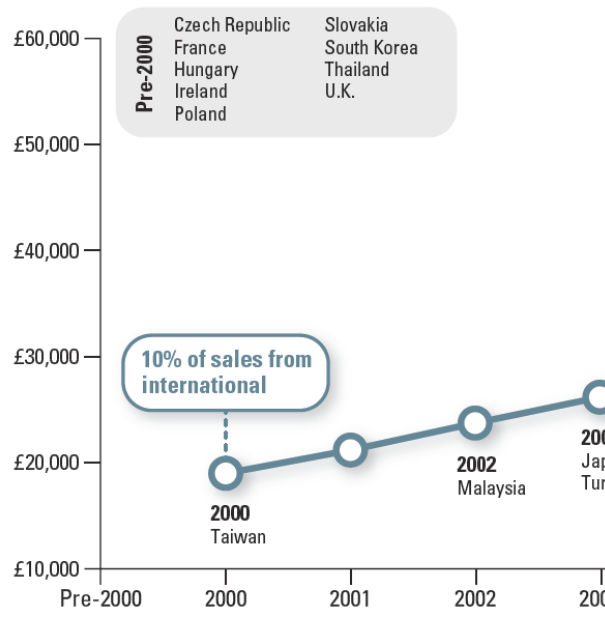

Source: http://www.atkearney.com/index.php/Publications/global-retail-development-index.html

\section{Figure 3: Expand and revenues of Tesco.}

The importance is further given to those chain stores which operate on the Slovak market and their expansion (measured in revenues), development and trendology is also highlighted. 


\section{Methodology of Research}

General Background of Research

It is important to know the position of the trade in the national economy, in Slovak economy, and its present impact on the economic development. The rate of trade on the amount of employees (in the chosen fields of national economy) is $19.75 \%$ and its rate in GDP is more than $70 \%$ (can be found at http://portal.statistics.sk/showdoc.do?docid=32176).

Various researches of consumers' behavior and preferences showed that Slovak customer copies the type of central European customer. The results of researches of GfK and INCOMA Company Research (Shopper Typology CEE, in 2010) noted that the most frequent type of Slovak consumer are so called "economist" and "communicative housewife". The shopping behavior of the first one may be described as a behavior when the consumer prefers huge department stores and discount stores, that of the second type is defined by preferences in discount stores with affordable prices, in shops with natural communication and finally in supermarkets offering wide range of products (Gubová, 2005). The structure of Slovak customer's purchase is mostly oriented to daily use products with orientation to the trademark of particular chain store. They are inseparable parts of chain stores' business practices as they should maintain attendance and loyalty of consumers. In the first years of chain stores' operation, these products were thought to be of low-class quality because of their lower prices. Recently, this way of thinking has been changed and as the research of GfK shows more than $80 \%$ of Slovak customers buy them without any prejudice and do not regard them as low-class. The aspect of trademarks by consumers is, however, completely different from the opinion which shares producers; different position, advantages and disadvantages are perceived. The production of trademark products is defined not only by advantages (lower costs by greater volume of production, better usage of production capacities and low- class material, profit, wide-spreading and possible entrance to foreign markets) but also another criterion is to be taken into consideration. The producers lose their identity and make their production anonymous and they partly reduce their position of producer as well as their position of negotiator in relation to chain stores. As it can be seen, the expansion of chain stores and various hyper and supermarkets is relevant, their strategy reflects the behavior and purchase of consumers.

\section{Sample of Research}

As mentioned below, the biggest and most successful stores in central European market are Tesco, Metro and retail group Schwarz-Groupe. By methods of data analysis, using the statistic data, annual reports and various financial statements, ten most important stores on Slovak market were recognized and processed. All the acquired data were analyzed, compared and afterward the ranking was set according to the turnover achieved. To have more relevant data the time period from 2009 to 2011 were taken into account.

\section{Results of Research}

The present trade has developed very dynamically and unpredictably. Few years ago it was unthinkable to imagine either huge retails or great department stores which are today inseparable part of people's lives. But not only trade has been in constant development but also the customers and environmental conditions. If one wants to describe the development of trade in our country, few time periods can be set. All the data was collected and on the basis on synthesis and analysis the following results can be determined. The first period began in the 90-s, when the Slovak Republic opened its borders to foreign traders and the foreign retailers 
PROBLEMS

OF MANAGEMENT IN THE $21^{\text {st }}$ CENTURY Volume 3, 2012

entered the market. One of the first retailers was the Tesco shop. This period is determined by the first competitive fight for customer. In the second period (mid 90-s) the market was enriched with various supermarkets and hypermarkets. The activities of traders on the market started to stagnate, supply was higher than demand and the customer market was developing turbulently. The beginning of the new century changed the customer preferences they focused on modern shop types. It was an increase in the number of department stores which provide also entertainment. It was absolutely new trend in purchasing. The last period has been developing since 2004/2005 when the strategy of low prices was applied (it was remarked by the entrance of Lidl store). Supply exceeds demand and this fact totally changed the shopping behavior. Since that time, the shopping centers have not been oriented to cities but to the centers of the middle-sized towns (Gubová, 2005).

In the central European zone (V4 countries) the best purchase results have been achieved by retails such as Metro, retail group of Schwarz-Groupe and British Tesco Stores. The entrance of transnational chain stores to the V4 zone was differentiated and in the Slovak Republic the most notable increase was noted in 2000. The best ranking in long-term horizon had the European chain stores, on the top with Tesco which achieved in 2006 record turnover of 27000 mil Slovak crowns (900 mil EUR). However, the Slovak chain stores were placed in the TOP 200 most successful nonfinancial companies, in the ranking of the biggest Slovak traders and in some partial assessment. The chain stores confirmed their market position by various marketing strategies, mostly in the forms of price bonuses, discounts, supplementary products etc. Considering the top ten chain stores, according to turnover achieved, the ranking may be seen in the Table 1. To complete the table the official websites of particular stores as well as their annual reports were considered. In 2009, as well as in 2010, the first three ranks were occupied by Tesco, Metro and Billa, but the difference is noticed in 2011, when one top position was replaced by Kaufland. The European prediction, that "the revenues of chain stores do not stagnate" despite the higher unemployment and lower purchase power was confirmed also in our country. The higher turnover can be caused by store's private trademarks which are sold is lower prices and that is why the bulk of consumers prefer purchasing them. So the position and significance of stores on the market grow, as the customers are more likely to purchase, because of wide range of products and other events and possibilities offered in all the chain stores.

Table 1. TOP 10 Slovak chain stores.

\begin{tabular}{|c|c|c|c|c|c|c|}
\hline Compa ny & $\begin{array}{l}\text { Turnover in mil. } \\
\qquad €(2009)\end{array}$ & Rank & $\begin{array}{l}\text { Turnover in mil. } € \\
\text { (2010) }\end{array}$ & Rank & $\begin{array}{c}\text { Turnover in mil. } € \\
\text { (2011) }\end{array}$ & Rank \\
\hline Tesco Stores SR & 1142,8 & 1. & 1170 & 1. & 1290 & 1. \\
\hline Metro Cash\&Carry & 460,5 & 2. & 478 & 3. & $192^{*}$ & 7. \\
\hline Billa & 439,8 & 3. & 487 & 2. & 506 & 3. \\
\hline Kaufland & 353,2 & 4. & 420 & 4. & 705 & 2. \\
\hline GG Tabak & 309,3 & 5. & 374 & 5. & 388 & 5. \\
\hline Ahold Retail Slovakia & 250 & 6. & 220 & 6. & 220 & 6. \\
\hline Lidl & 177,1 & 7. & 184 & 7. & 390 & 4. \\
\hline Nay & 174,5 & 8. & 181 & 8. & 184,7 & 8. \\
\hline CBA Slovakia & 163 & 9. & 163 & 9. & 174,2 & 9. \\
\hline Baumax SR & 124,5 & 10. & 135 & 10. & 124 & 10. \\
\hline
\end{tabular}

Considering Table 1, the market segmentation can be done according to the turnover achieved. Moreover, the typology of chain stores may be described. Man can distinguish three 
segments. Firstly, all the chain stores with revenues up to 250 mil EUR, secondly, the more successful stores (the revenues from 250-500 mil EUR), finally the top stores if the revenues are higher than 500 mil EUR in a period of a year.

\section{Discussion}

The significant characteristics of the present retail stores can be described in following style: the time of production of everything for everyone is definitely over, the market segmentation and the consumer typology have an important role, purchase is influenced by shopping category, shopping opportunities or location of shopping. The higher the criteria of consumers the more differentiate the supply of traders.

As the revenues and turnovers of particular stores, supermarkets and hypermarkets have increased (as it may be seen also on the expansion of stores' turnovers in the Slovak Republic) their high standard of operation is proved. The European prediction was proved also in the Slovak Republic which means that consumers prefer shopping in those kinds of shops which offer more diversiform, quality and price affordable products. Whereas, the chain stores are really powerful which allow them to manage relation and cooperation with producer and supplier and set requirements on variety, fluid and quality of assortment. So far the development showed that Slovak consumers are not prepared enough to face all the problems, tricks and competition on the market. The level of consumer policy is the proof. Practice of Slovak traders is in a comparison with that of foreign one more balanced. In the Slovak Republic there are as many chain stores as required by market, region and consumer. The massive phase of Slovak trade expansion is definitely over. In the next few years the change of quantitative expansion into the qualitative is predicted. One of the important prerequisites is to increase the quality of services provided and the usage of the newest technologies.

\section{Conclusions}

The specification of trade in the national economy is significantly influenced by the existence of trade as of the most important linking between the producer and the consumer. The consumers cannot be isolated from their behavior and from macro a micro structures of the society. The complex model of consumer behavior has to be defined to help traders fulfill the consumers' needs (Vysekalová, 2011, p. 35). Firstly, it has to be said that traders play an important role in the purchase process and the process itself makes the mutual interaction much easier. Retail traders are, on the other hand, indicators of the national economic health. The level of the trade in a particular country is measured and monitored by the level of trade, density and quality of trade networks, product assortment, variety of supply, product freshness, price, behavior and qualification of employees, etc. Last but not least, constant contact with consumer is necessary. It helps traders to follow and then predict their reaction to the various market stimuli.

Consumer market, in general, is an important part of every national economy. That is why the organizational consumer markets have to be perceived very precisely. They have its own structure and typology and the further their expansion the more important role they play in the market. As they offer not only the shopping services, but also some kind of entertainment, bulk of consumer prefer them. According to the study it was proved that despite the recession in the European economies the revenues of chain stores do not stagnate also on the Slovak market. 
PROBLEMS

OF MANAGEMENT

IN THE $21^{\text {st }}$ CENTURY

Volume 3, 2012

\section{References}

Dzurová, M. (2007). Spotrebitel'ské teórie a reálie. Bratislava: Vydavatel’stvo Ekonóm.

Gubová, M. (2005). Vplyv obchodných ret'azcov na slovenský trh. Retrieved 16/02/2012, from http:// www.vuepp.sk/anotacie_studie08/142.pdf

Hawkins, I., Best, J., Coney, A. (1991). Consumer behavior; Implication for marketing strategy. (5. ed.). U.S.A: Irwin.

Higham, W. (2010). Trendológia the Next Big Thing: Ako rozpoznat' a predpokladat' budúce trendy $v$ správaní zákaznikov. Bratislava: Eastone Books.

Majtán, Š. (2007). Odbytová stratégia. Bratislava: Vydavatel’stvo Ekonóm.

Stašenková, B. (2006). Prečo a ako vzdelávat'spotrebitel'a. Bratislava: Metodicko- pedagogické centrum Bratislavského kraja

Steffens, H. (2006). Správanie spotrebitel’ov a spotrebitel'ská politika. Bratislava: Vydavatel'stvo Ekonóm

Š́bl, D. et al (2002). Vel'ká ekonomická encyklopédia. Bratislava: SPRINT

Vysekalová, J. (2011). Chování zákazníka: Jak odkrýt tajemnství “černé skřinky”. Praha: Grada Publishing.

Zamazalová, M. (2009). Marketing obchodni firmy. Praha: Grada Publishing.

The list of Slovak chain stores (n.d.). Retrieved 16/02/2012, from http://greenpages.spectator.sme.sk/sk/ c/velkoobchod-a-obchodne-retazce.html

Metro group website and annual and financial reports (n.d.). Retrieved 16/02/2012, from http://www metrogroup.de/internet/site/metrogroup/node/9251/Len/index.html

Tesco website and annual and financial reports (n.d.). Retrieved 16/02/2012, from http://www.itesco.sk/.

Rewe-group website and annual and financial reports (n.d.). Retrieved 16/02/2012, from http://www. rewe-group.com/en/company/annual-reports/.

Kaufland website and annual and financial reports (n.d.). Retrieved 16/02/2012, from http://www. kaufland.sk/Home/05_Spolocnost/index.jsp.

GG Tabak website and annual and financial reports (n.d.). Retrieved 16/02/2012, from http://www. ggtabak.sk/

Ahold group website and annual and financial reports (n.d.). Retrieved 16/02/2012, from http://www. ahold.sk/jnp/sk/ahold/home/index.html

Lidl website and annual and financial reports (n.d.). Retrieved 16/02/2012, from http://www.lidl.sk/cps/ rde/xchg/lidl_sk/hs.xsl/index.htm

NAY website and annual and financial reports (n.d.). Retrieved 16/02/2012, from http://www.nay.sk/

CBA website and annual and financial reports (n.d.). Retrieved 16/02/2012, from http://www.cbaslovakia.sk/

Baumax website and annual and financial reports (n.d.). Retrieved 16/02/2012, from http://baumax.sk/c/ $\mathrm{cms} /$ frontpage

Labaš website and annual and financial reports (n.d.). Retrieved 16/02/2012, from http://www.labas.sk/ sk/

The Global Retail Development Index: A 10-year Retrospective. Retrieved 20/02/2012, from http://www. atkearney.com/index.php/Publications/global-retail-development-index.html 
Katarína LEHUTOVÁ, Štefan CISKO. Typology and Trendology of Organizational Consumer Markets in the Slovak Republic

Advised by Elena Gregová, University of Žilina, Žilina, Slovak Republic $\begin{aligned} & \text { PROBLEMS } \\ & \text { OF MANAGEMENT } \\ & \text { IN THE 21st CENTURY } \\ & \text { Volume 3, 2012 }\end{aligned}$

Received: February 03, 2012

Accepted: March 12, 2012

\begin{tabular}{|ll|}
\hline Katarína Lehutová & Ing. Postgradual Student, University of Žilina, Faculty of Operation and \\
& Economics of Transport Und Communications, Department of Economics, \\
Univerzitná 1,010 01 Žilina, Slovak Republic. \\
E-mail: katarina.lehutova@fpedas.uniza.sk
\end{tabular}

